\title{
Validation of Temperature Measurements from the Airborne Raman Ozone Temperature and Aerosol Lidar During SOLVE
}

\author{
John Burris, Thomas McGee and Walter Hoegy
}

Laboratory for Atmospheres, Goddard Space Flight Center, Greenbelt, Md. 20771

Leslie Lait, Laurence Twigg and Grant Sumnicht

Science Systems and Applications, Inc. 5900 Princess Garden Parkway, Lanham, Md. 20706

William Heaps

The Instrument Technology Center, Goddard Space Flight Center, Greenbelt, Md. 20771

Chris Hostetler

Radiation and Aerosols Branch, Mail Stop 435, Langley Research Center, Hampton, Va. 23681-2199

T. Paul Bui

Mail Stop 245-5, Ames Research Center, Moffett Field, Ca. 94035

Roland Neuber

Alfred Wegner Institute for Polar Research, Telegrafenberg A43, D-14473 Potsdam, Germany

I. Stuart McDermid

Table Mountain Facility, Jet Propulsion Laboratory, Wrightwood, Ca. 92397

Abstract. The Airborne Raman Ozone, Temperature and Aerosol Lidar (AROTEL) participated in the recent Sage III Ozone Loss and Validation Experiment (SOLVE) by providing profiles of aerosols, polar stratospheric clouds (PSCs), ozone and temperature with high vertical and horizontal resolution. Temperatures were derived from just above the aircraft to $\sim 60$ kilometers geometric altitude with a reported vertical resolution of between 0.5 and $1.5 \mathrm{~km}$. The horizontal footprint varied from 4 to $70 \mathrm{~km}$. This paper explores the measurement uncertainties associated with the temperature retrievals and makes comparisons with independent, coincident, measurements of temperature. Measurement uncertainties range from $0.1 \mathrm{~K}$ to $\sim 4 \mathrm{~K}$ depending on altitude and integration time. Comparisons between AROTEL and balloon sonde temperatures retrieved under clear sky conditions using both Rayleigh and Raman scattered data showed AROTEL $\sim 1 \mathrm{~K}$ colder than sonde values. Comparisons between AROTEL and the Meteorological Measurement System (MMS) on NASA's ER-2 show AROTEL being from $2-3 \mathrm{~K}$ colder for altitudes ranging from 14 to $18 \mathrm{~km}$. Temperature comparisons between AROTEL and the United Kingdom Meteorological Office's model showed differences of approximately $1 \mathrm{~K}$ below $\sim 25 \mathrm{~km}$ and a very strong cold bias of $\sim 12 \mathrm{~K}$ at altitudes between 30 and $35 \mathrm{~km}$. 


\section{Introduction}

NASA Goddard Space Flight Center's Airborne Raman, Ozone, Temperature and Aerosol Lidar (AROTEL) participated in the SAGE III Ozone Loss and Validation Experiment (SOLVE) campaign during the winter of 1999/2000. This campaign, conducted jointly with the Third European Stratospheric Experiment on Ozone (THESEO), was based in Kiruna, Sweden and combined measurements from ground, balloon, aircraft and space-based platforms to study the processes governing ozone loss within the polar stratosphere. A second goal of the SOLVE campaign was to have been the validation of data products from the SAGE III instrument had it been launched. A key measurement for both satellite validation and ozone loss was temperature. Temperature plays a critical role in determining both the extent and duration of polar stratospheric clouds (PSCs) on whose surfaces inactive reservoir species are converted to reactive species that destroy ozone. Lidar temperature retrievals from an aircraft platform provide a unique data set that is acquired simultaneously with other onboard measurements. Retrievals can be made at times and locations inaccessible to a satellite instrument thereby affording a more comprehensive picture of atmospheric phenomena. AROTEL temperature retrievals offered significantly better vertical and horizontal resolution than was possible with a satellite instrument; the horizontal footprint can be varied between 4 and 70 kilometers while the reported vertical resolution extends from 500 to 1500 meters depending on altitude and integration time. In this paper we will present comparisons between AROTEL temperatures and those derived from coincident balloon sondes measurements. Comparisons between AROTEL temperatures and those retrieved by the Meteorological Measurement System (MMS) on the ER-2 will be made for dates on which the DC-8 and ER-2 flew coincident tracks. A study of temperature differences between AROTEL and those derived from the United Kingdom Meteorological Office (UKMO), National Centers for Environmental Prediction (NCEP) and NASA Goddard Space Flight Center's Data Assimilation Office (DAO) models will be made.

\section{Instrument and Technique}

AROTEL is a Rayleigh/Raman lidar that utilizes a hardware configuration previously validated on other Goddard Space Flight Center lidars. Temperature data was acquired using a laser operating at a wavelength of $355 \mathrm{~nm}$. This wavelength permitted the use of strong Rayleigh and Raman UV backscattering while avoiding signal attenuation from the temperature dependent Huggins ozone band. Photon counting was utilized for data acquisition because of its large dynamic range and sensitivity to low signal levels. Photomultiplier tubes (PMTs), pulse height discriminators and multi-channel scalar cards constituted the detection system and were employed for all channels. Wavelength discrimination was provided by bandpass filters with $\sim 1 \mathrm{~nm}$ bandpass and high transmission. Filters enabled the design of a compact detector with high detection efficiency but restricted temperature retrievals to solar zenith angles (SZAs) > 95 degrees. A complete discussion of the AROTEL instrument is provided in McGee et al. [this issue]. AROTEL's operational characteristics relevant to the temperature measurement are provided in Table 1.

AROTEL temperatures were retrieved using an algorithm proven in numerous previous field campaigns, a discussion of issues relating to the temperature retrieval is covered in Gross et al.[1997]. Temperatures were derived from data created by both elastic (Rayleigh) molecular scattering and inelastic (Raman) scattering by molecular nitrogen. These data are directly proportional to atmospheric number density. Temperatures are calculated using relative, not absolute, number densities thus making the retrieval insensitive to many instrumental parameters such as telescope size, photomultiplier tube quantum efficiency and detector transmission efficiency. Elastic scattering, with returns $\sim 2000$ times more intense than those from inelastic backscattering, provided numerous advantages such as more distant ranging, enhanced vertical resolution, better signal to noise and more rapid data acquisition. The sensitivity of elastic molecular scattering to interference by Mie scattering from aerosols, thin cirrus and PSCs, however, limited its use to altitudes above $20-25 \mathrm{~km}$ (unless otherwise noted all altitudes are geometric). Because of the wavelength shift associated with inelastic scattering $\left(\sim 2331 \mathrm{~cm}^{-1}\right.$ for $\left.\mathrm{N}_{2}\right)$, it is, to first order, not affected by Mie scattering from clouds and aerosols. Reported inelastic temperature retrievals extend from the aircraft 
to $\sim 25 \mathrm{~km}$ altitude, elastic retrievals are reported to $\sim 45 \mathrm{~km}$. Besides temperature, AROTEL provided several additional data products including ozone profiles to $\sim 30 \mathrm{~km}$ and both backscatter and extinction data for aerosols at $355 \mathrm{~nm}$. NASA's Langley Research Center (LaRC) used data derived from scattering at 532 and $1064 \mathrm{~nm}$ to calculate aerosol backscattering and extinction coefficients and depolarization ratios (532 nm). These data were acquired simultaneously with the AROTEL aerosol (UV), ozone and temperature retrievals.

Table 1. AROTEL Instrument

$\begin{array}{lcc}\text { Wavelength }(\mathrm{nm}) & 355 & 387 \\ \text { Energy/pulse } & 200 \text { millijoules } \\ \text { Repetition rate } & 50 \mathrm{~Hz} \\ \text { Receiver diameter } & 40 \mathrm{~cm} \\ \text { Effective area }\left(\mathrm{cm}^{2}\right) & \sim 1240 \\ \text { Altitude range }(\mathrm{km}) & 12-60 & 12-25 \\ \text { Data bin size }(\text { meters }) & 150 & 150 \\ & & \\ \text { Horizontal resolution } & 4.0-70 \mathrm{~km} \\ \text { Vertical resolution } & 0.5-1.5 \mathrm{~km} \\ \text { Precision } & <1-4 \mathrm{~K}<1-5 \mathrm{~K}\end{array}$

\section{Measurement Uncertainties}

Temperature uncertainties, in the absence of optically thick clouds and aerosols, are influenced by several mechanisms. Below $\sim 40 \mathrm{~km}$, statistical errors inherent in photon counting are the most important. These errors depend critically upon whether elastic or inelastic returns are used because of the marked differences in scattering cross section between the two processes. Rayleigh scattering of both the laser pulse and return signal can cause significant signal loss for both elastic and inelastic data, a correction is applied to all data. Since the instrument actually measures the local atmospheric density profile this correction is made using the retrieved density. Signals are also impacted by the desired vertical and horizontal resolution, the range between aircraft and scattering volume and how the signal is partitioned between the various detectors. The large dy namic range in returns from just above the aircraft to beyond $60 \mathrm{~km}$ altitude requires splitting the return signals among multiple PMTs. Intense returns can introduce nonlinearities in the PMT's background count rate that make it difficult to ascertain the true count rate for low signal levels. These non-linearities were minimized by gating (effectively setting the PMT gain to zero while the outward propagating laser pulse is still close to the lidar). Extremely high count rates also affect signal linearity because of discriminator saturation, a correction to convert observed into actual counts was made. Except in the presence of optically thick clouds, extremely high count rates were generally not an issue because all PMTs were operated in a regime where the background counts remained linear.

Additional noise sources included dark counts associated with the PMTs (minimal) and counts that, depending upon operational conditions, originated with the sun or moon and fell within the detector's bandpass. Aurora were observed on several occasions but their emission was outside the instrument's detection bandpass. For temperature retrievals the full capability of the instrument was realized for solar zenith angles (SZA) $\geq 95$ degrees, however, temperatures were derived for SZAs as low as 85 degrees. As the SZA decreased, the increased solar background restricted the maximum altitude of the measurement and significantly impacted the measurement uncertainty due to the high background count rates.

The retrieval algorithm must be initialized and this introduces a uncertainty above $\sim 40 \mathrm{~km}$. Temperatures were calculated using a routine initialized at the maximum altitude of the retrieval, typically 
between 54 and $60 \mathrm{~km}$. Initialization was accomplished utilizing either a model (CIRA86) or temperature profile calculated using data from the Data Assimilation Office at Goddard Space Flight Center for the aircraft's projected flight track. Errors using DAO temperatures at the $0.5 \mathrm{mbar}$ pressure level are $\leq 5 \mathrm{~K}$ (Steve Pawson - private communication). At $40 \mathrm{~km}$ the impact of the DAO tie-on uncertainty is $<0.7 \mathrm{~K}$ and at $30 \mathrm{~km}$ it falls below $0.1 \mathrm{~K}$. Using a model to tie-on at $60 \mathrm{~km}$ can introduce larger uncertainties since it is based upon the general climatology. The CIRA86 model provided temperatures, pressures and densities from 0 to $120 \mathrm{~km}$ in $5 \mathrm{~km}$ intervals based on both monthly and zonal averages. CIRA86 and DAO generally differed by less than $10 \mathrm{~K}$ at the tie on altitude, this introduced an error in the retrieved temperatures at 35 $\mathrm{km}$ of $<0.5 \mathrm{~K}$.

In addition to clear air, temperatures can be retrieved above optically thin clouds and aerosols, however, the additional signal attenuation increases reported errors. Temperatures can occasionally be derived above optically thick clouds depending on signal levels. Temperature retrievals within optically thick PSCs or aerosol layers are not considered here because of the inability to adequately correct for Mie scattering and signal attenuation. Neither can they be derived below optically thick clouds. Retrievals within clouds are made using inelastic scattering. A detailed discussion of temperature profiling within optically thin clouds and aerosol layers will be discussed in an upcoming paper currently in preparation.

Measurement uncertainties as a function of altitude for both the Rayleigh and Raman temperatures are given in Figure 1.

\section{AROTEL and Balloon Sonde Temperatures}

During SOLVE, the DC-8 made numerous overflights of the Network to Detect Stratospheric Change (NDSC) site at Ny Âlesund, on Spitsbergen island, as part of a correlative measurements effort. Balloon sondes were launched to coincide with DC-8 overflights of the island and thereby provide ozone and temperature profiles from within the same volume sampled by AROTEL. Other sonde sites used for validation included two sites on Greenland's east coast (Danmarkshavn and Scoresbvsund), Iceland (Keflavik) and two Norwegian (Jan Mayen and Bjornoya Island) sites. Several issues developed in using sondes as part of a correlative measurement effort. The first arose because sonde observations were not always coincident the DC-8's flight track, either in time or space. For the comparisons reported here the maximum horizontal distance between the DC-8 and sonde launch site was less than or equal to $100 \mathrm{~km}$, the largest separation in time between the sonde and DC-8's closest approach was $\sim 11$ hours. Lidar temperatures within \pm 150 meters of a reported sonde altitude were averaged together for the comparison. The second issue concerned the relatively low bursting altitude of the meteorological sondes, 20 to $25 \mathrm{~km}$, which prevented the acquisition of a good data set within the $25-35 \mathrm{~km}$ region. Figure 2 presents a plot of sonde versus lidar temperatures for flight date December 7, 1999.

Mean differences between AROTEL and all balloon sonde temperature data used in the comparison as a function of altitude are given in terms of elastic and inelastically derived temperatures in Figures 3 and 4. Reported uncertainties in sonde temperatures at $100 \mathrm{mbar}(\sim 15 \mathrm{~km})$ are $\leq 0.5 \mathrm{~K}, \sim 1 \mathrm{~K}$ at $20 \mathrm{mbar}(\sim 26$ $\mathrm{km})$ and $\sim 4 \mathrm{~K}$ at $10 \mathrm{mbar}(\sim 30 \mathrm{~km})$ [Schmidlin, 1988]. Sonde temperatures are reported over altitude intervals ranging from $\sim 10$ to $\sim 1000$ meters. For temperatures derived from elastically scattered returns, the AROTEL minus sonde difference was $-1.1 \pm 0.6 \mathrm{~K}$ between 12 and $28 \mathrm{~km}$. The mean difference for inelastically determined temperature was $-1.2 \pm 1.1 \mathrm{~K}$ between 12 and $26 \mathrm{~km}$ altitude. No systematic differences were found between the lidar and sonde temperature measurements as a function of the sonde's distance from closest approach to the aircraft's flight track and for time differences of up to 11 hours (the maximum difference).

\section{AROTEL and MMS Temperature Comparison}

Several opportunities for correlative measurements with the ER-2's MMS became available during SOLVE. MMS provides a number of data products including pressure, horizontal and vertical winds and insitu temperature at the ER-2's flight altitude [Scott et al., 1990]. Temperatures are derived from a resistive 
measurement on an open platinum wire calibrated against a NIST standard. Corrections to the static temperature were made for thermodynamic heating as a function of the aircraft's MACH number. On January 20,2000 both the DC-8 and ER-2 followed essentially the same flight track from Kiruna towards the North Pole and back again. The criteria employed to define coincidence on this flight required the measurement sites differ by no more than $30 \mathrm{~km}$ horizontally and be separated by less than 10 minutes in time. This test provided numerous coincidence pairs between $\sim 14.5 \mathrm{~km}$ and $18 \mathrm{~km}$ geometric altitude. Since PSCs were observed by the co-located LaRC aerosol lidar during significant portions of the flight, inelastic temperatures were utilized because of their relative insensitivity to optically thin PSCs and aerosols. The data indicated that AROTEL had a cold bias of approximately $2.5 \pm 0.9 \mathrm{~K}$ compared to reported MMS temperatures (Figure 5). AROTEL temperatures were calculated using a 5 minute data set and had reported errors ranging from $\sim 0.4$ to $1.0 \mathrm{~K}$ over this altitude range; the effective vertical resolution was $\sim 0.5 \mathrm{~km}$. MMS has a reported precision of $0.3 \mathrm{~K}$, an accuracy of $0.2 \%(\sim 0.4 \mathrm{~K}$ for this altitude) and one second resolution. On both January 27, 2000 and March 5, 2000 additional comparisons were made between MMS and AROTEL temperatures retrieved employing both elastic and inelastic returns. The criteria for coincidence used here was $30 \mathrm{~km}$ horizontally and $\leq 5$ hours in time. Inelastic data for January $27^{\text {th }}$ had a mean difference between AROTEL and MMS of $-2.8 \pm 0.5 \mathrm{~K}$ while the March $5^{\text {th }}$ flight demonstrated a mean difference of $-1.9 \pm 0.2 \mathrm{~K}$. Temperatures calculated using elastic returns also displayed a cold bias with respect to MMS of $-2.0 \pm 1.8 \mathrm{~K}$ for January $27^{\text {th }}$, for March $5^{\text {th }}$ a bias of $-2.6 \pm 0.8 \mathrm{~K}$ was observed. All measurements demonstrated that both the inelastic and elastically derived AROTEL temperatures were from 2 to $3 \mathrm{~K}$ colder than reported MMS values.

\section{Ny Alesund and Mauna Loa Temperatures: Lidar and Sondes}

As a result of the observed cold temperature biases in AROTEL temperatures when compared against both MMS and the balloon sondes a study was undertaken of temperatures retrieved by Goddard's STROZ-LITE Ozone and Temperature lidar during two previous field campaigns. This is a mobile system installed inside a trailer with a 39" telescope, a xenon chloride excimer laser operating at $308 \mathrm{~nm}$ and a xenon fluoride excimer at $351 \mathrm{~nm}$. Temperature data is derived from elastically scattered data at $351 \mathrm{~nm}$ and inelastically scattered returns at $382 \mathrm{~nm}$ [McGee et al., 1995]. The close physical similarity between the STROZ-LITE and AROTEL lidars and the utilization of a similar temperature algorithm by both instruments suggested a study utilizing STROZ-LITE's more extensive data base could help identity the origin of these biases. The data sets chosen included a winter campaign at the Arctic NDSC site on Spitsbergen Island, Ny Ålesund, during 1998 and a summer campaign at a site on Mauna Loa in Hawaii during 1995. Specific questions were whether biases had been observed in the data during these two campaigns and, if so, what were their magnitude and sign. An additional opportunity for an independent correlative study was provided by Stuart McDermid's JPL lidar also located on Mauna Loa during the same 1995 campaign [McDermid et al., 1991].

The Ny Allesund study consisted of ten dates in January and February of 1998 during which correlative measurements were made. A total of 1373 separate temperature differences were calculated. Lidar retrievals began at $\sim 10 \mathrm{~km}$ with a reported altitude resolution of from 1 to $3 \mathrm{~km}$ depending on altitude. Reported uncertainties ranged from 0.1 to $0.5 \mathrm{~K}$ for data sets acquired with $\sim 60$ minutes of data. Data retrieved in the presence of PSCs was not used in the comparison. The comparison showed that the lidar temperatures had a small cold bias relative to the sondes of $\sim-1.4 \pm 1.9 \mathrm{~K}$ over altitudes between 15 to $\sim 32$ km (Figure 6).

A second correlative measurements opportunity involved the NDSC intercomparison campaign on the island of Hawaii during August and September, 1995. Numerous temperature retrievals were made by STROZ-LITE and compared to balloon sondes, another ground-based lidar (McDermid) and National Meteorological Center (NMC) values. Balloon sondes were launched from Hilo, Hawaii and timed to coincide with data acquisition by the lidars. As with the Ny Alesund data, the Mauna Loa intercomparison showed that the STROZ-LITE lidar exhibited a slight cold bias relative to the sondes (Figure 7). A total of 16 dates were employed and the resulting biases ranged from $\sim 0 \mathrm{~K}$ at $15 \mathrm{~km}$ to $\sim-4 \mathrm{~K}$ at $30 \mathrm{~km}$. The reported altitude resolution varied with altitude from 1 to $3 \mathrm{~km}$; measurement uncertainties ranged from $\sim 0.1 \mathrm{~K}$ at $15 \mathrm{~km}$ to 
$\sim 0.5 \mathrm{~K}$ at $30 \mathrm{~km}$ for approximately 90 minutes of data. Another temperature and ozone lidar on Mauna Loa, operated by Stuart McDermid of JPL, also provided temperature profiles available for comparison with balloon sonde profiles during 1995. An identical analysis was performed for the same time frame as above using data reported by McDermid and again a slight cold bias was observed in the lidar temperatures relative to the sondes (see figure 8). This bias ranged from $\sim 2.1 \mathrm{~K}$ at $15 \mathrm{~km}$ to $\sim 0$ at $20 \mathrm{~km}$ and $\sim-2 \mathrm{~K}$ at $35 \mathrm{~km}$. The reported altitude resolution varied between 1 and $6 \mathrm{~km}$. Reported measurement uncertainties as a function of altitude were between $0.2 \mathrm{~K}$ and $1 \mathrm{~K}$

These results suggest that temperatures derived from lidar data have a small but real cold bias when compared to temperatures retrieved by balloon sondes regardless of whether the data was acquired in the tropics or Arctic. The differences observed from these ground-based measurements are consistent with those observed by AROTEL during the SOLVE campaign $(-1.2 \pm 1.1 \mathrm{~K}$ for inelastically derived temperatures, $-1.1 \pm 0.6 \mathrm{~K}$ for temperatures derived from elastically scatter data).

\section{Model Temperatures}

A correlative study was carried out using AROTEL temperatures and those calculated by three global gridded meteorological analyses: the NASA Goddard Space Flight Center's Data Assimilation Office (DAO) product, the United Kingdom Meteorological Office (UKMO) product generated for the Upper Atmosphere Research Satellite (UARS) project, and data reanalysis generated by National Centers for Environmental Prediction (NCEP) and the National Center for Atmospheric Research (NCAR). All three are generated by data assimilation procedures in which satellite, rawindsonde, and other measurements are merged into a running model so that the resulting data are consistent with both the measurements and atmospheric physics.

The DAO fields for the SOLVE period are obtained from the GEOS-3 assimilation system for EOS-Terra support. GEOS-3 is the successor to the GEOS-1 system documented in Pfaendtner et al. [1995]. These data grids lie on 36 pressure levels ranging from $1000 \mathrm{hPa}$ to $0.2 \mathrm{hPa}$, have a horizontal resolution of one degree longitude by one degree latitude, and are produced at $0000,0600,1200$, and 1800 UTC each day.

The UKMO UARS fields are supplemental correlative data for the UARS Project and are described in Swinbank and O'Neil [1994]. The version used here are grids which consist of 18 pressure surfaces from $1000 \mathrm{hPa}$ to $0.4 \mathrm{hPa}$, have a horizontal resolution of 3.75 degrees longitude by 2.5 degrees latitude, and are produced at 1200 UTC daily.

The NCEP/NCAR reanalysis system's procedures are applied consistently to over 40 years of raw data, resulting in a dataset which is useful for long-term studies. (For further information, see Kalney et al., 1996). These data consist of 17 pressure surfaces from $1000 \mathrm{hPa}$ to $10 \mathrm{hPa}$, have a horizontal resolution of 2.5 degrees longitude by 2.5 degrees latitude, and are produced at $0000,0600,1200$, and 1800 UTC daily.

Differences between lidar and model were calculated for temperatures retrieved using elastic and inelastic returns on all flight dates for which data was reported. Temperature retrievals employing elastic backscatter within PSCs were excluded as were retrievals using inelastic data within or below optically thick clouds. The flights on December 7, 1999 and December $12^{\text {th }}$ were representative of dates during which PSCs were and were not observed by the co-located LaRC lidar. Differences were calculated for all three models and are qualitatively similar however we present only the UKMO results here. Between flight altitude $(10-12 \mathrm{~km})$ and $\sim 25 \mathrm{~km}$ the mean difference between AROTEL inelastic temperatures and UKMO temperatures for December 7, 1999 was $0.7 \pm 1.9 \mathrm{~K}$, for December 12, 1999 AROTEL was slightly colder: $-1.0 \pm 1.3 \mathrm{~K}$ (Figures 9 and 10 ). Elastically derived temperatures to $\sim 40 \mathrm{~km}$ for December 7 were marginally colder than the models, $-2.4 \pm 4.4 \mathrm{~K}$; for December 12 , AROTEL was again slightly colder, $-2.8 \pm 4.2 \mathrm{~K}$. Elastically derived temperatures between 32 and $33 \mathrm{~km}$ altitude repeatedly showed large cold biases with respect to the models (Figures 11 and 12). For December $7^{\text {th }}$ the mean difference between AROTEL and UKMO at $32.8 \mathrm{~km}$ was $-12.6 \pm 1.4 \mathrm{~K}$. The December $12^{\text {th }}$ differences were $-12.3 \pm 2.2 \mathrm{~K}$ at $32.6 \mathrm{~km}$. When these altitudes are removed from the calculation the mean difference between AROTEL and UKMO for December $7^{\text {th }}$ was $-0.6 \pm 1.3 \mathrm{~K}$, for December $12^{\text {th }}$ it was $-1.2 \pm 1.6 \mathrm{~K}$ which are consistent with differences 
derived for the inelastically derived temperatures.

The large differences between AROTEL and model temperatures in the region of from $\sim 30$ and 35 $\mathrm{km}$ were surprising given the much small differences observed between AROTEL and both MMS and balloon sonde temperatures. As was previously done for the sonde measurements, data sets acquired by the STROZ-LITE lidar during deployments to both polar and tropical sites were used for comparisons with model forecast made from $\sim 10 \mathrm{~km}$ to over $50 \mathrm{~km}$ altitude. To provide a consistent model temperature product for previously acquired data only results from the UKMO model were used for these comparison. Data from the Arctic site at Ny Allesund provided temperatures on 17 dates between January 20, 1998 and February 9 1998. Differences between STROZ-LITE and UMKO were calculated between 10 and $\sim 40 \mathrm{~km}$ altitude (Figure 13). The mean difference between STROZ-LITE and UKMO was $-1.1 \pm 8.8 \mathrm{~K}$ for altitudes from 10.8 to $38.7 \mathrm{~km}$. There was a slight cold bias of $\sim 1 \mathrm{~K}$ from 10 to $22 \mathrm{~km}$ which increased to over $9 \mathrm{~K}$ at $32.6 \mathrm{~km}$. Reported temperature errors for these data sets range from 0.1 at $10 \mathrm{~km}$ to $0.3 \mathrm{~K}$ at $38 \mathrm{~km}$ with an effective vertical resolution of between 1 and $3 \mathrm{~km}$.

The STROZ-LITE data set acquired at Mauna Loa in 1995 and used in the sonde comparison above was also compared to UKMO temperature profiles for the specified dates. Here, unlike Ny Alesund, the UKMO temperatures displayed much better agreement with the lidar as shown in Figure 14. Data was acquired on 16 dates from August 15, 1995 through September 1, 1995. A slight cold bias was noted between 30 and $40 \mathrm{~km}$, at $31.3 \mathrm{~km}$ the mean difference between lidar and UKMO was $-2.0 \mathrm{~K}$ and at $36.1 \mathrm{~km}$ it was $-2.7 \mathrm{~K}$. Differences were calculated from $14.2 \mathrm{~km}$ to $55.2 \mathrm{~km}$ with a mean difference of $-0.9 \mathrm{~K}$. Calculated uncertainties ranged from $\sim 0.1 \mathrm{~K}$ to $\sim 0.6 \mathrm{~K}$ at $55 \mathrm{~km}$. The lidar's reported vertical resolution ranged from $1 \mathrm{~km}$ at the lower end to $\sim 3 \mathrm{~km}$ at $30 \mathrm{~km}$ and, because most of the signal was directed at the high altitude channel, $\sim 2 \mathrm{~km}$ at $55 \mathrm{~km}$.

Temperatures derived from data acquired by the JPL lidar were also compared to those from the UKMO model. For the previously reported data set, JPL reported a slight cold bias of $-0.5 \mathrm{~K}$ averaged over data from 14.3 to $55.4 \mathrm{~km}$ (Figure 15). The largest biases were noted at $36.0 \mathrm{~km}$ at $-5.0 \mathrm{~K}$. Typical errors for the JPL measurements ranged from 0.2 to $1.0 \mathrm{~K}$ with a reported vertical resolution of from $\sim 1.0$ to $7 \mathrm{~km}$. These results suggest that between 30 to $40 \mathrm{~km}$ altitude, systematic biases exist between the lidars and models. Both the JPL lidar and STROZ-LITE had, with respect to the UKMO temperatures, a slight cold bias in the tropics while STROZ-LITE and AROTEL displayed much larger temperature differences against UKMO in the polar regions; the origin of these differences in the polar region is not known but may be due to the limited number of soundings available to the modeling community within this altitude range.

\section{Conclusions}

AROTEL temperatures, retrieved during the SOLVE campaign, have been compared with those from balloon sondes and the MMS instrument onboard the ER-2. A slight cold bias was found in both comparisons; when compared to MMS the difference varied between 2-3 K while temperatures derived from balloon sondes were $1.2 \pm 1.1 \mathrm{~K}$ warmer than inelastically derived AROTEL temperatures and $1.1 \pm 0.6 \mathrm{~K}$ warmer than temperatures derived from elastically scattered data. AROTEL temperatures, when compared to several temperature models (DAO, NCEP and UKMO), showed differences that were less than or equal to $1 \mathrm{~K}$ below $\sim 30 \mathrm{~km}$. Between $30-40 \mathrm{~km}$ AROTEL displayed a large cold bias of $12 \mathrm{~K}$ against the UKMO model. Significant temperature biases at these altitudes were also observ ed in data acquired by another Goddard lidar, STROZ-LITE, during a winter campaign correlative measurements campaign at Ny Allesund in 1998. These cold biases were significantly smaller in data acquired in Hawaii during a 1995 campaign. The good agreement between AROTEL and model below $30 \mathrm{~km}$ altitude suggest the discrepancy above 30 $\mathrm{km}$ is due to the limited number of retrievals available for use by the models in the polar region.

Acknowledgments.

The authors would like to acknowledge the support provided by NASA's Upper Atmosphere Research Program for both the Airborne Raman Ozone, Temperature and Aerosol Lidar (AROTEL) and SOLVE mission. We would like to thank the many members of the DC-8 support team at Dryden Flight Research Center for

their support in all facets of the instrument's installation and operation. And finally Don Silbert did a
keeping both lasers and computers operational during the many critical hours of airborne operation. 


\section{References:}

Gross, M., T.J. McGee, R.A. Ferrare, U.N. Singh and P. Kimvilakani, Temperature measurements made with a combined Rayleigh-Mie and Raman lidar, Appl. Opt. 36, 5987-5994, 1997.

Kalnay, E., M. Kanamitsu, R. Kistler, W. Collins, D. Deaven, L. Gandin, M. Iredell, S. Saha, G. White, J. Woollen, Y. Zhu, M. Chelliah, W. Ebisuzaki, W. Higgins, J. Janowiak, K. C. Mo, C. Ropelewski, J. Wang, A. Leetmaa, R. Reynolds, R. Jenne, and D. Joseph, The NCEP/NCAR 40-year reanalysis project, Bull. Am. Met. Soc., 77, 437-471, 1996.

McDermid, I. S., D. A. Haner, M. M. Kleinman, T. D. Walsh and M. L. White, Differential Absorption Lidar Systems for Tropospheric and Stratospheric Ozone Measurements, Opt. Eng., 30, 22-30, 1991.

McGee, T. J., M. Gross, U. N. Singh, J. J. Butler and P. Kimvilakani, An Improved Stratospheric Ozone Lidar, Opt. Eng., 34, 1421-1430, 1995.

McGee, T. J., J. Burris, L. Twigg, Wm. Heaps, G. Sumnicht, W. Hoegy and C. Hostetler, AROTEL: An Airborne Ozone, Aerosol and Temperature Lidar, this issue.

Pfaendtner, J., S. Bloom, D. Lamich, M. Seablom, M. Sienkiewicz, J. Stobie, and A. da Silva, Documentation of the Goddard Earth Observing System (GEOS) Data Assimilation System - Version 1, NASA Technical Memorandum 104606, Vol. 4, 1995.

Schmidlin, F. J., Instrument and Observing Methods: WMO International Radiosonde Intercomparison Phase II, 1985, WMO Rep. 29, WMO/TD-32, World Meteorol. Organ., Geneva, 1988.

Scott, S. G., K. R. Chan, S. W. Bowen, and T. P. Bui, The Meteorological Measurement System on the NASA ER-2 aircraft, J. Atmos. Oceanic Technol., 7, 525-540, 1990.

Swinbank, R., and A. O'Neil, A stratosphere-troposphere data assimilation system, Mon. Wea. Rev., 122, 686-702, 1994. 


\section{Figure Captions}

Figure 1. Temperature uncertainties versus altitude for temperatures derived from elastic (Rayleigh) and inelastically (Raman) scattered data for flight date 991207. Open circles are inelastic temperature errors, solid squares are for elastically derived temperature errors.

Figure 2.

Figure 3. AROTEL (elastic) temperatures minus all sonde temperature retrievals that occurred within

Balloon sonde versus AROTEL inelastic temperatures acquired on flight date 991207 over Ny Ålesund. The sonde's maximum altitude was almost $27 \mathrm{~km}$. The minimum temperature was $\sim 190 \mathrm{~K}$ at $25 \mathrm{~km}$ in good agreement with AROTEL at $189 \mathrm{~K}$. $100 \mathrm{~km}$ and 12 hours of a DC-8 flight track. The mean difference between AROTEL and the sondes was $-1.1 \pm 0.6 \mathrm{~K}$ between 12 and $28 \mathrm{~km}$ altitude.

Figure 4. AROTEL (inelastic) temperatures minus all sonde temperature retrievals acquired within $100 \mathrm{~km}$ and 12 hours of a DC-8 flight track. The mean difference between lidar and sonde was $-1.2 \pm 1.1 \mathrm{~K}$ between 12 and $26 \mathrm{~km}$ altitude.

Figure 5.

AROTEL (inelastic) - MMS temperature differences for flight date 000120 . Coincidences were for MMS retrievals made within $30 \mathrm{~km}$ and 10 minutes of the DC-8 flight track. The mean difference was $-2.5 \pm 0.9 \mathrm{~K}$.

Figure 6.

Figure 7.

STROZ-LITE minus balloon sonde temperatures for Ny Alesund deployment in 1998. The mean difference was $-1.4 \pm 1.9 \mathrm{~K}$ between 15 and $30 \mathrm{~km}$.

STROZ-LITE minus balloon sonde temperatures for Mauna Loa campaign in 1995 . The mean temperature difference was $-1.5 \pm 2.0 \mathrm{~K}$. At $15 \mathrm{~km}$ the difference was $+0.5 \pm 1.3 \mathrm{~K}$; at $20 \mathrm{~km},-1.5 \pm 1.0 \mathrm{~K}$; at $25 \mathrm{~km},-1.9 \pm 0.7 \mathrm{~K}$; at $30 \mathrm{~km},-4.0 \pm 1.4 \mathrm{~K}$ and at $35 \mathrm{~km}$ the difference was $-0.2 \pm 1.3 \mathrm{~K}$.

Figure 8. JPL - sonde temperatures for Mauna Loa campaign in 1995. The computed mean difference was $0.0 \pm 1.7 \mathrm{~K}$.

Figure 9. Temperature difference plot of AROTEL minus UKMO for December 7, 1999. AROTEL temperatures were derived using inelastically scattered data. The mean difference was $-0.7 \pm 1.9 \mathrm{~K}$.

Figure 10. Temperature difference plot of AROTEL minus UKMO for December 12, 1999. AROTEL temperatures were derived using inelastically scattered data. The mean difference was $-1.0 \pm 1.3 \mathrm{~K}$.

Figure 11. Temperature difference plot of AROTEL minus UKMO for December 7, 1999. AROTEL temperatures were derived using elastically scattered data. The mean difference was $-2.4 \pm 4.4 \mathrm{~K}$. The mean difference at $32.8 \mathrm{~km}$ was $-12.6 \pm 1.4 \mathrm{~K}$. Removing the value at 32.8 $\mathrm{km}$ results in a mean difference between AROTEL and UKMO of $-0.6 \pm 1.3 \mathrm{~K}$. Figure 12. Temperature difference plot of AROTEL minus UKMO for December 12, 1999. AROTEL
temperatures were derived using elastically scattered data. The mean difference was $-2.8 \pm 4.2 \mathrm{~K}$. The mean difference at $32.6 \mathrm{~km}$ was $-12.3 \pm 2.2 \mathrm{~K}$. Calculating the temperature difference without including the large perturbation at $32.6 \mathrm{~km}$ gives a value of $-1.2 \pm 1.6 \mathrm{~K}$.

Figure 13. STROZ-LITE minus UKMO model temperatures at Ny Allesund during the 1998 NDSC campaign. Differences between STROZ-LITE and UMKO were calculated between 10 and 
$\sim 40 \mathrm{~km}$ altitude. The mean difference between STROZ-LITE and UKMO was $-2.7 \pm 4.2 \mathrm{~K}$ for altitudes from 10 to $40 \mathrm{~km}$. There was a slight cold bias of $\sim 1 \mathrm{~K}$ from 10 to $22 \mathrm{~km}$ which increased to over $9 \mathrm{~K}$ at $32.6 \mathrm{~km}$. Reported temperature errors for these data sets range from 0.1 at $10 \mathrm{~km}$ to $0.3 \mathrm{~K}$ at $38 \mathrm{~km}$ with an effective vertical resolution of between 1 and

Figure 14. STROZ-LITE minus UKMO model temperatures during the Mauna Loa NDSC correlative measurements campaign in 1995. Data was acquired on 16 dates from August $15^{\text {th }}$ through September $1^{\text {st }}, 1995$. A slight cold bias was noted between 30 and $40 \mathrm{~km}$, at $31.3 \mathrm{~km}$ the mean difference between lidar and UKMO was $-2.0 \pm 2.5 \mathrm{~K}$ and at $36.1 \mathrm{~km}$ it was $-2.8 \pm 2.2$ $K$. Differences were calculated from $14.2 \mathrm{~km}$ to $55.2 \mathrm{~km}$ with a mean difference of $-0.9 \pm$ $2.7 \mathrm{~K}$. Calculated uncertainties ranged from $\sim 0.1 \mathrm{~K}$ to $\sim 0.6 \mathrm{~K}$ at $55 \mathrm{~km}$. The lidar's resolution ranged from $1 \mathrm{~km}$ at the lower end to $\sim 3 \mathrm{~km}$ at $30 \mathrm{~km}$ and back to $2 \mathrm{~km}$ at $55 \mathrm{~km}$. Figure 15. JPL - UKMO model temperatures during the Mauna Loa NDSC campaign in 1995 . The JPL
data had a slight cold bias of $-0.5 \pm 3.0 \mathrm{~K}$ averaged between 14.3 and $55.4 \mathrm{~km}$ altitude. The largest bias was noted at $36.0 \mathrm{~km}$ at $-5.0 \pm 1.8 \mathrm{~K}$. Typical errors for the JPL measurements ranged from 0.2 to $1.0 \mathrm{~K}$ with a reported vertical resolution of from $\sim 1.0$ to $7 \mathrm{~km}$. 


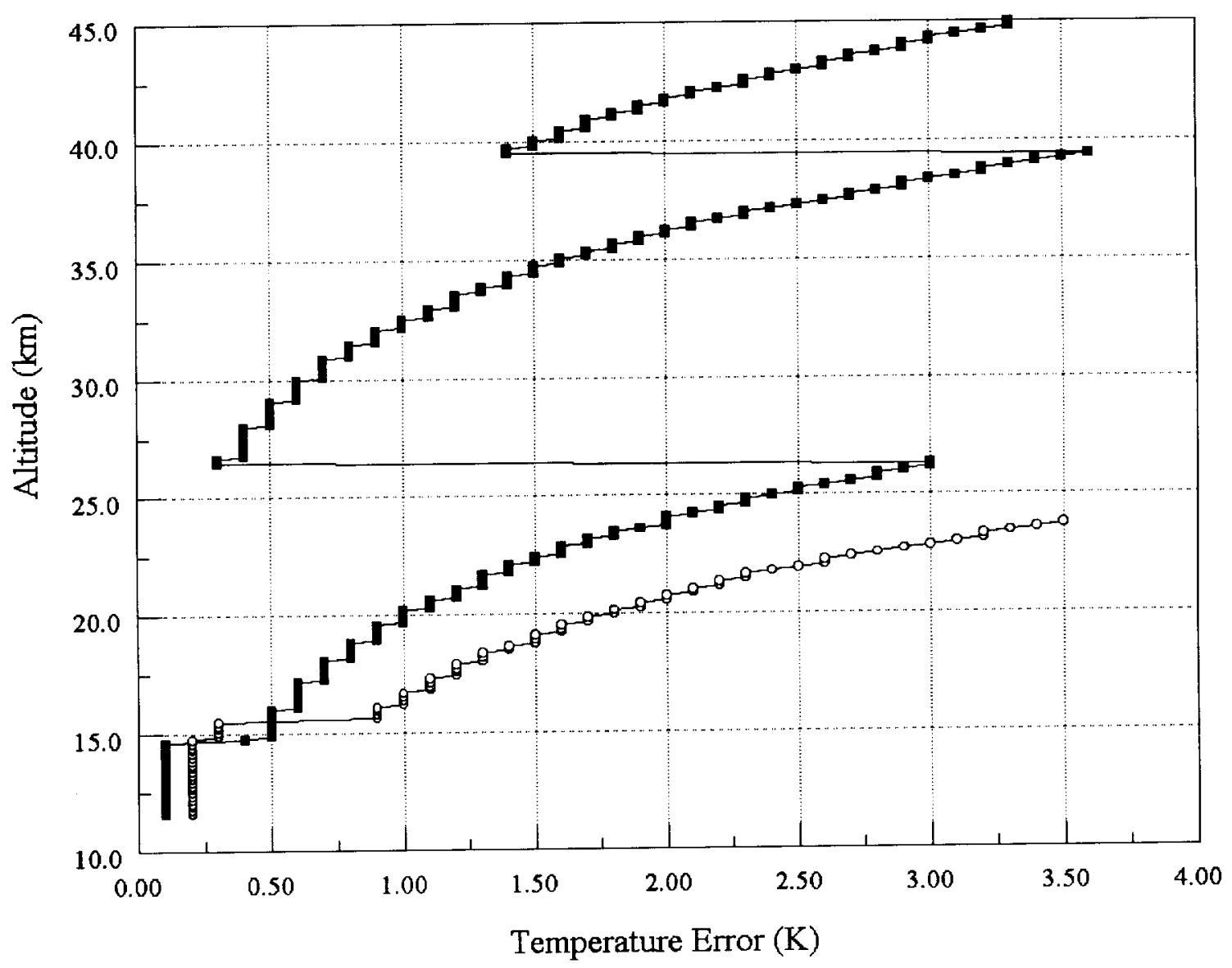

Figure 1 Temperature uncertainties versus altitude for temperatures derived from elastic (Rayleigh) and inelastically (Raman) scattered data for flight 991207. Open circles are inelastic temperature errors, solid squares are for elastically derived temperature errors. 


\section{December, 1999}

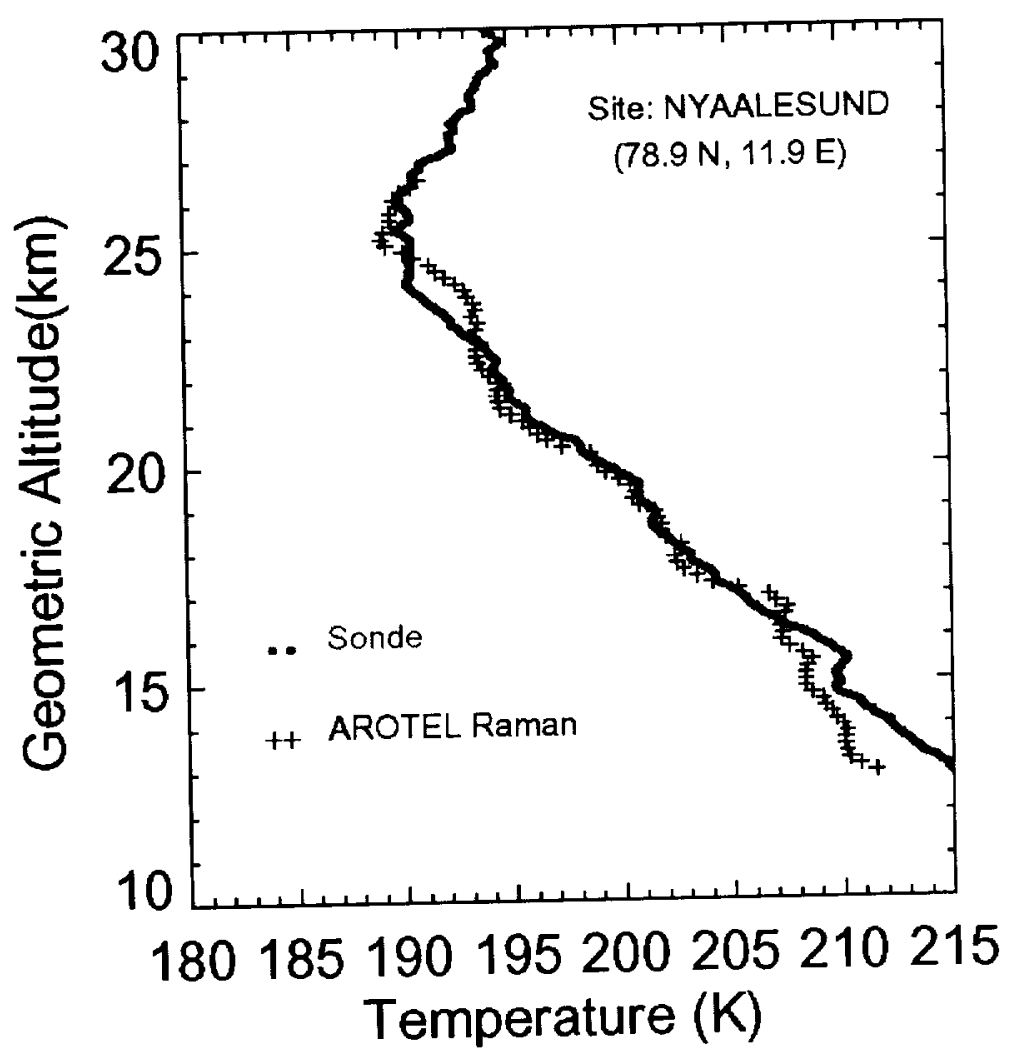

Figure 2 Balloon sonde versus AROTEL inelastic temperatures acquired on flight date 991207 over Ny Ålesund. The sonde's maximum altitude was almost $27 \mathrm{~km}$. The minimum temperature was $\sim 190 \mathrm{~K}$ which was in good agreement with AROTEL at $\sim 189 \mathrm{~K}$. 


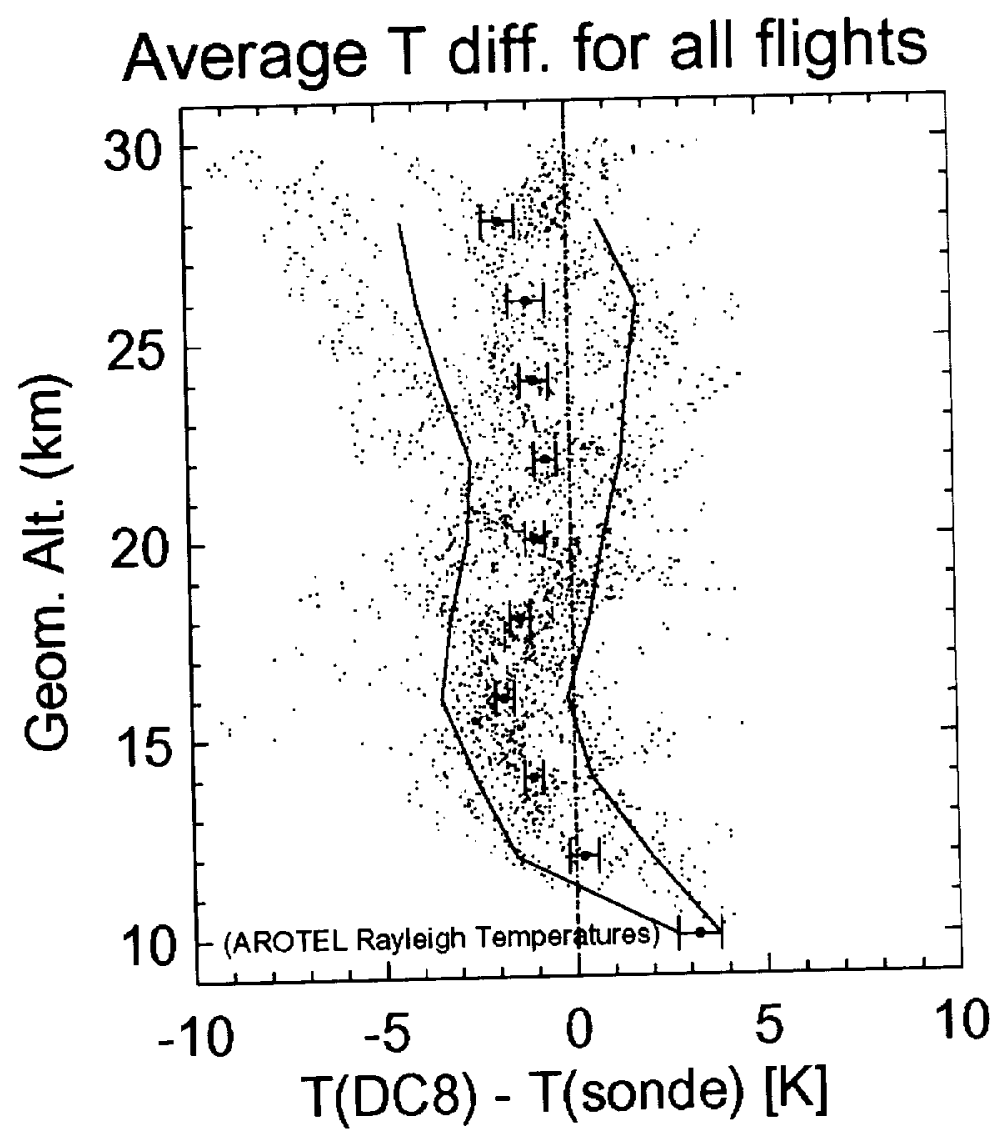

Figure 3 AROTEL (elastic) temperatures minus all sonde temperature retrievals that occurred within $100 \mathrm{~km}$ and 12 hours of a DC-8 flight track. The mean difference between AROTEL and the sondes was $-1.1 \pm 0.6 \mathrm{~K}$ between 10 and $28 \mathrm{~km}$. 


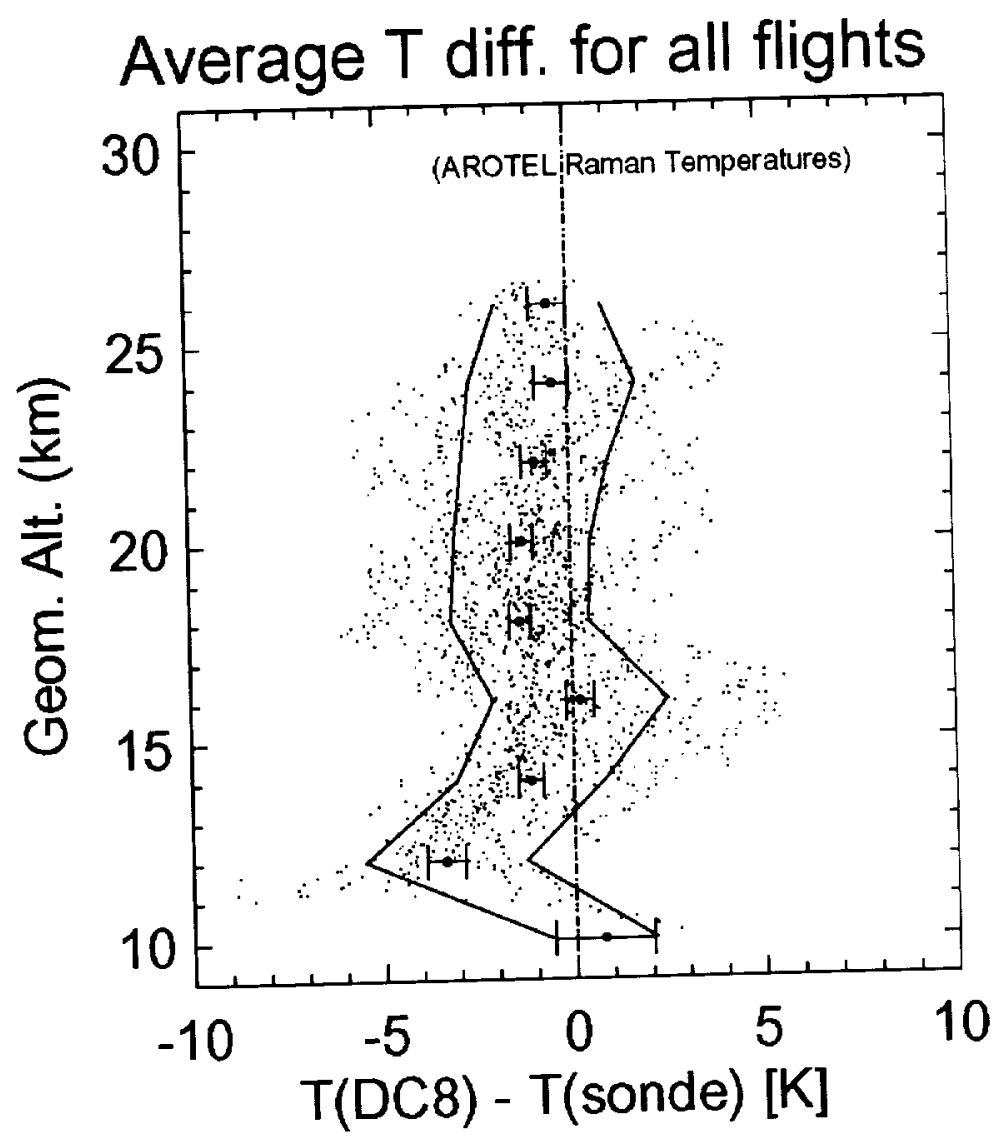

Figure 4 AROTEL (inelastic) temperatures minus all sonde temperature retrievals acquired within $100 \mathrm{~km}$ and 12 hours of a DC-8 flight track. The mean difference between AROTEL and sonde was $-1.0 \pm 1.1 \mathrm{~K}$ between 12 and $26 \mathrm{~km}$. 


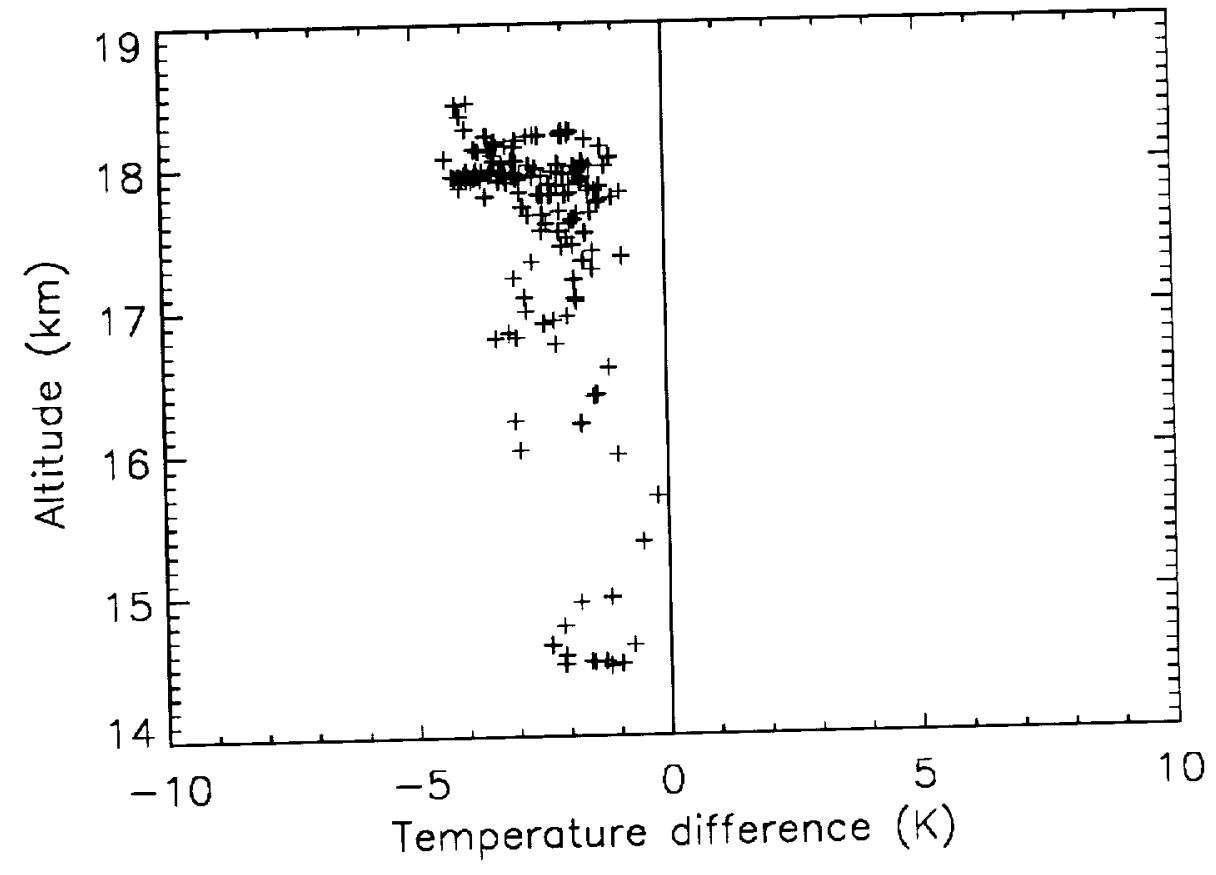

Figure 5 AROTEL (inelastic) - MMS temperature differences for flight date 000120. Coincidences were for MMS retrievals made within $30 \mathrm{~km}$ and 10 minutes of the DC-8 flight track. The mean difference was $-2.5 \pm 0.9 \mathrm{~K}$. 


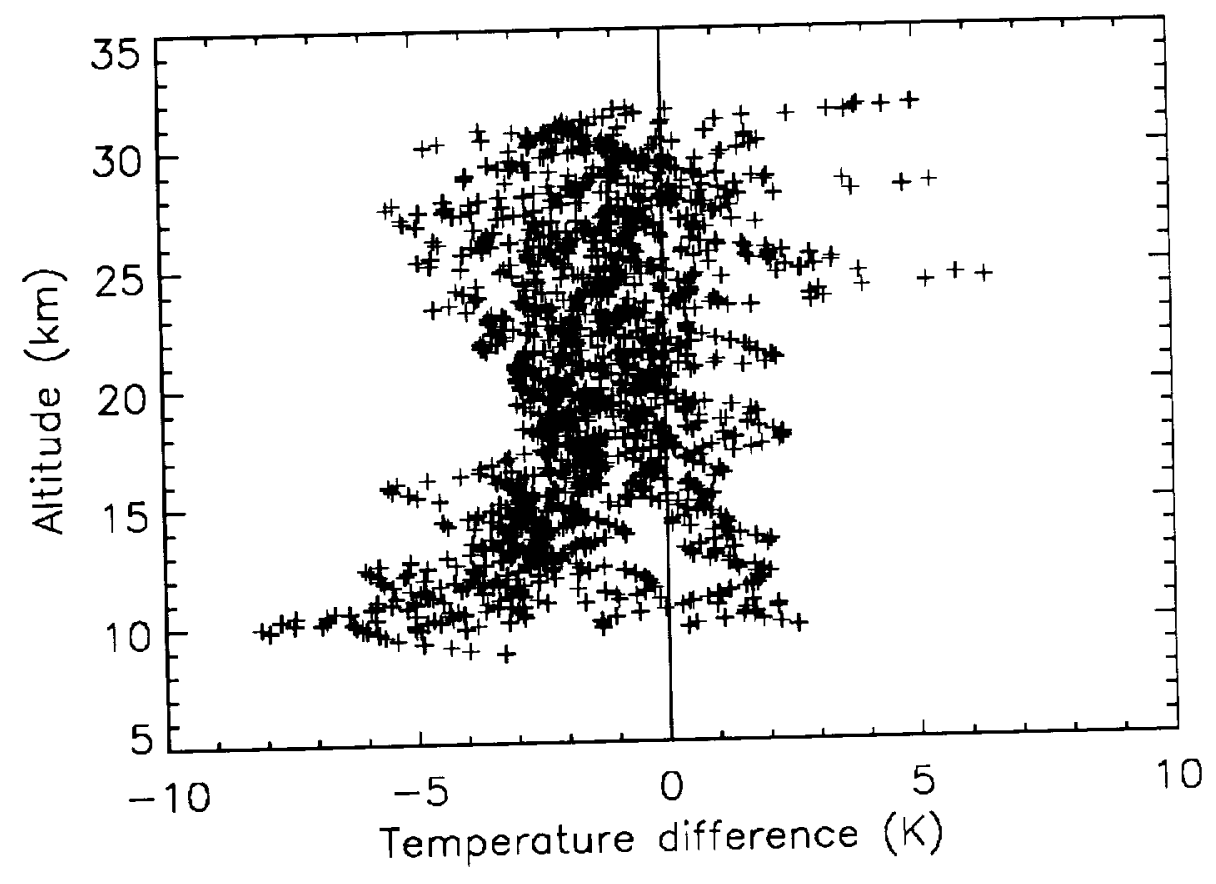

Figure 6 STROZ-LITE minus balloon sonde temperatures for the Ny Ålesund deployment in 1998 . The mean difference was $-1.4 \pm 1.9 \mathrm{~K}$ between 15 and $30 \mathrm{~km}$. 


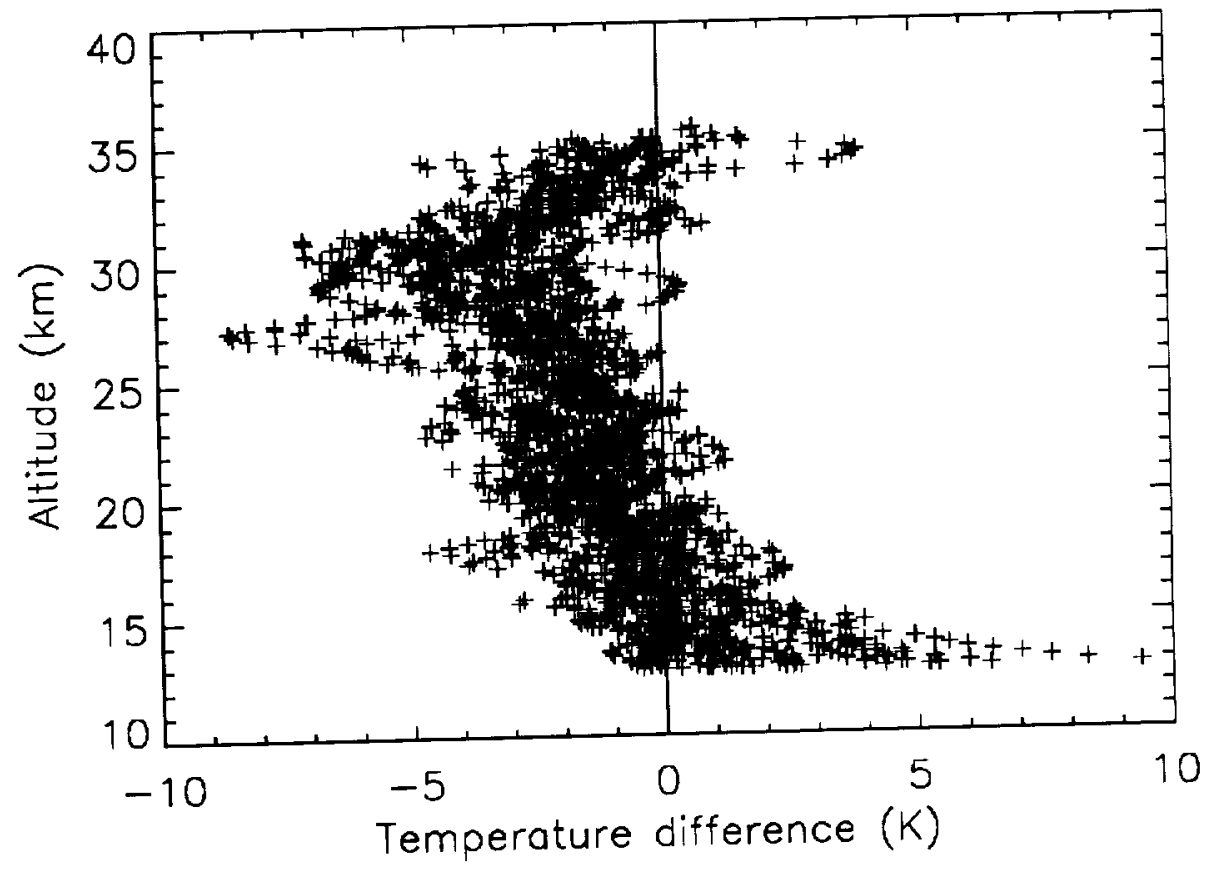

Figure 7 STROZ-LITE minus balloon sonde temperatures for the Mauna Loa campaign in 1995. The mean temperature difference was $-1.5 \pm 2.0 \mathrm{~K}$. At $15 \mathrm{~km}$ the difference was $+0.5 \pm 1.3 \mathrm{~K}$; at $20 \mathrm{~km},-1.5 \pm 1.0 \mathrm{~K}$; at $25 \mathrm{~km},-1.9 \pm 0.7 \mathrm{~K}$; at $30 \mathrm{~km},-4.0 \pm 1.4 \mathrm{~K}$ and at $35 \mathrm{~km}-0.2 \pm 1.3 \mathrm{~K}$. 


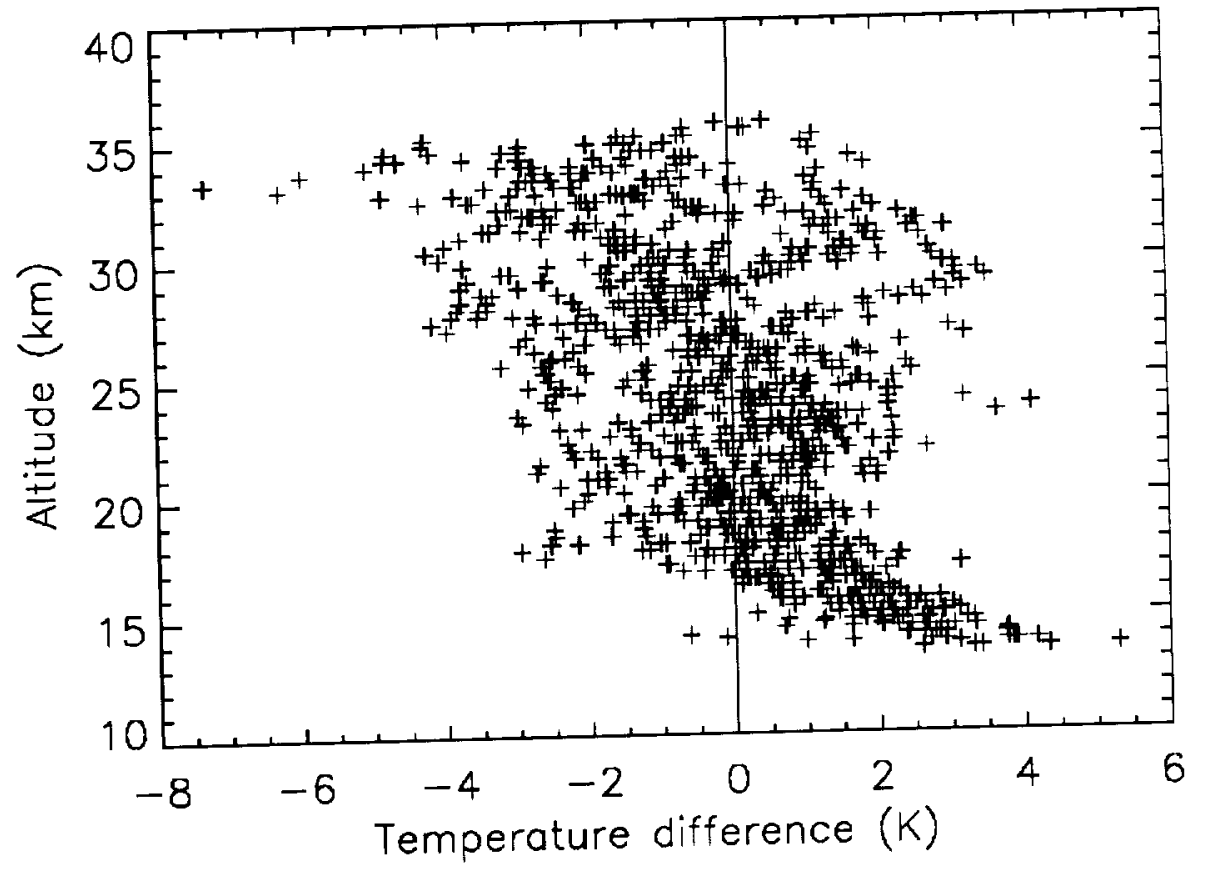

Figure 8 JPL - sonde temperatures for Mauna Loa campaign in 1995. The computed mean difference was $0.0 \pm 1.7 \mathrm{~K}$. 


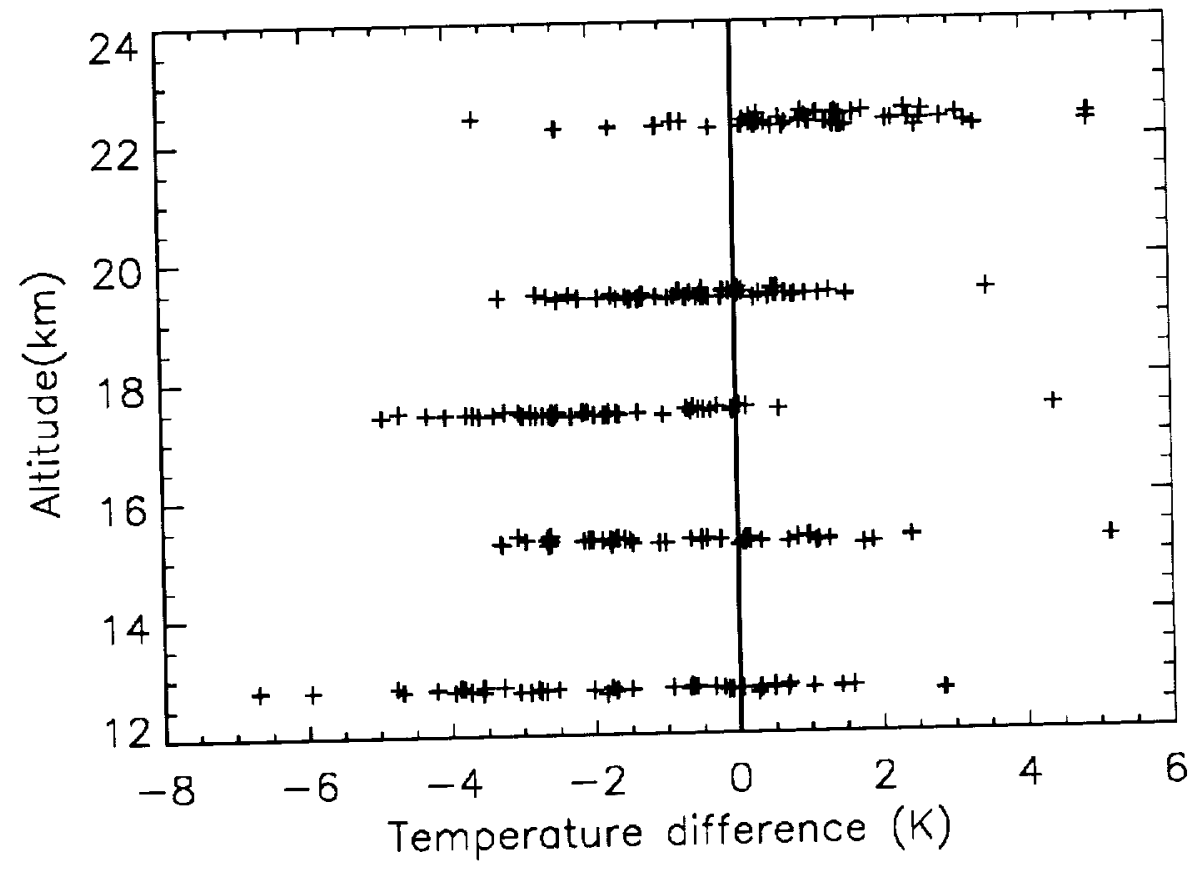

Figure 9 Temperature difference plot of AROTEL minus UKMO for December 7, 1999. AROTEL temperatures were derived using inelastically scattered data. The mean difference was $-0.7 \pm 1.9 \mathrm{~K}$. 


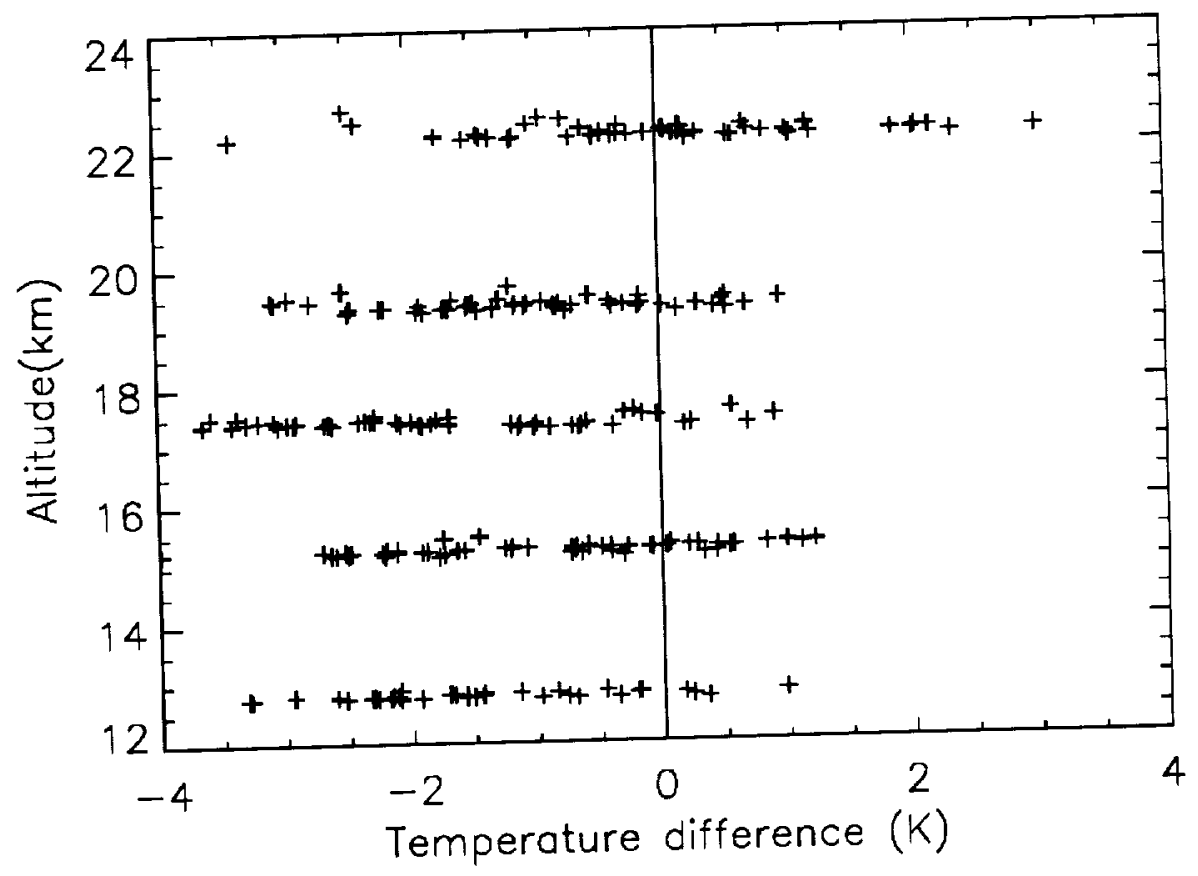

Figure 10 Temperature difference plot of AROTEL minus UKMO for December 12, 1999. AROTEL temperatures were derived using inelastically scattered data. The mean difference was $-1.0 \pm 1.3 \mathrm{~K}$. 


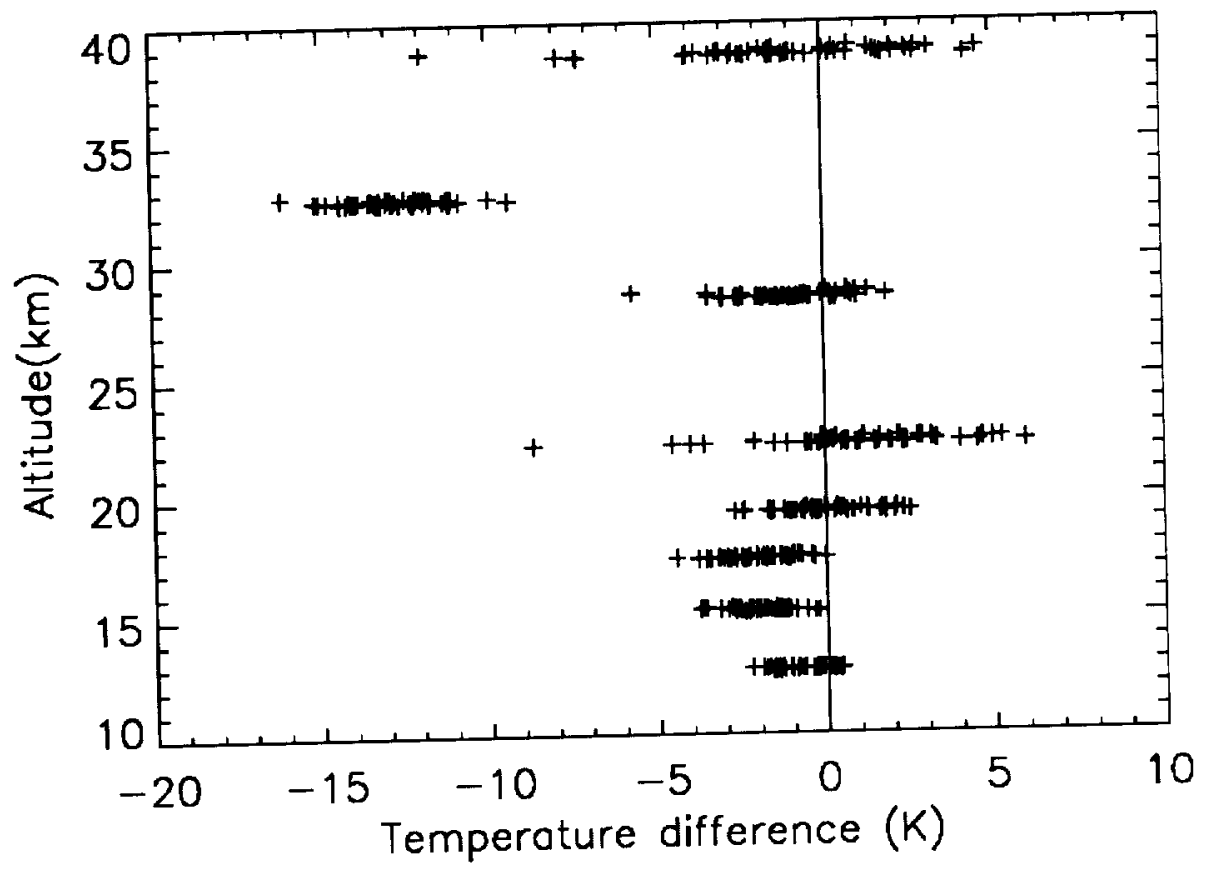

Figure 11 Temperature difference plot of AROTEL minus UKMO for December 7, 1999. AROTEL temperatures were derived using elastically scattered data. The mean difference was $-2.4 \pm 4.4 \mathrm{~K}$. The mean difference at $32.8 \mathrm{~km}$ was $-12.6 \pm 1.4 \mathrm{~K}$. Removing the value at $32.8 \mathrm{~km}$ results in a mean difference between AROTEL and UKMO of $-0.6 \pm 1.3 \mathrm{~K}$. 


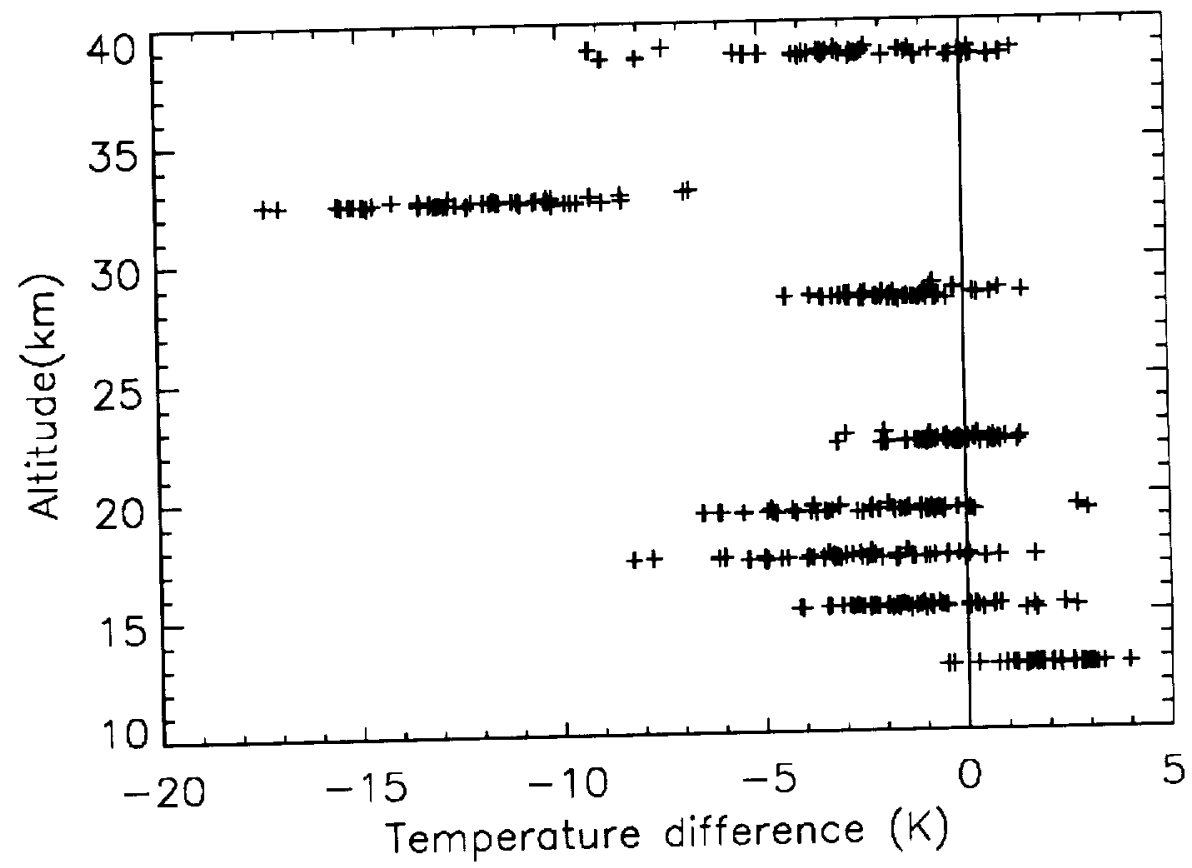

Figure 12 Temperature difference plot of AROTEL minus UKMO for December 12, 1999. AROTEL temperatures were derived using elastically scattered data. The mean difference was $-2.8 \pm 4.2 \mathrm{~K}$. The mean difference at $32.6 \mathrm{~km}$ was $-12.3 \pm 2.2 \mathrm{~K}$. Calculating the temperature difference without including the large perturbation at $32.6 \mathrm{~km}$ gives a value of $-1.2 \pm 1.6 \mathrm{~K}$. 


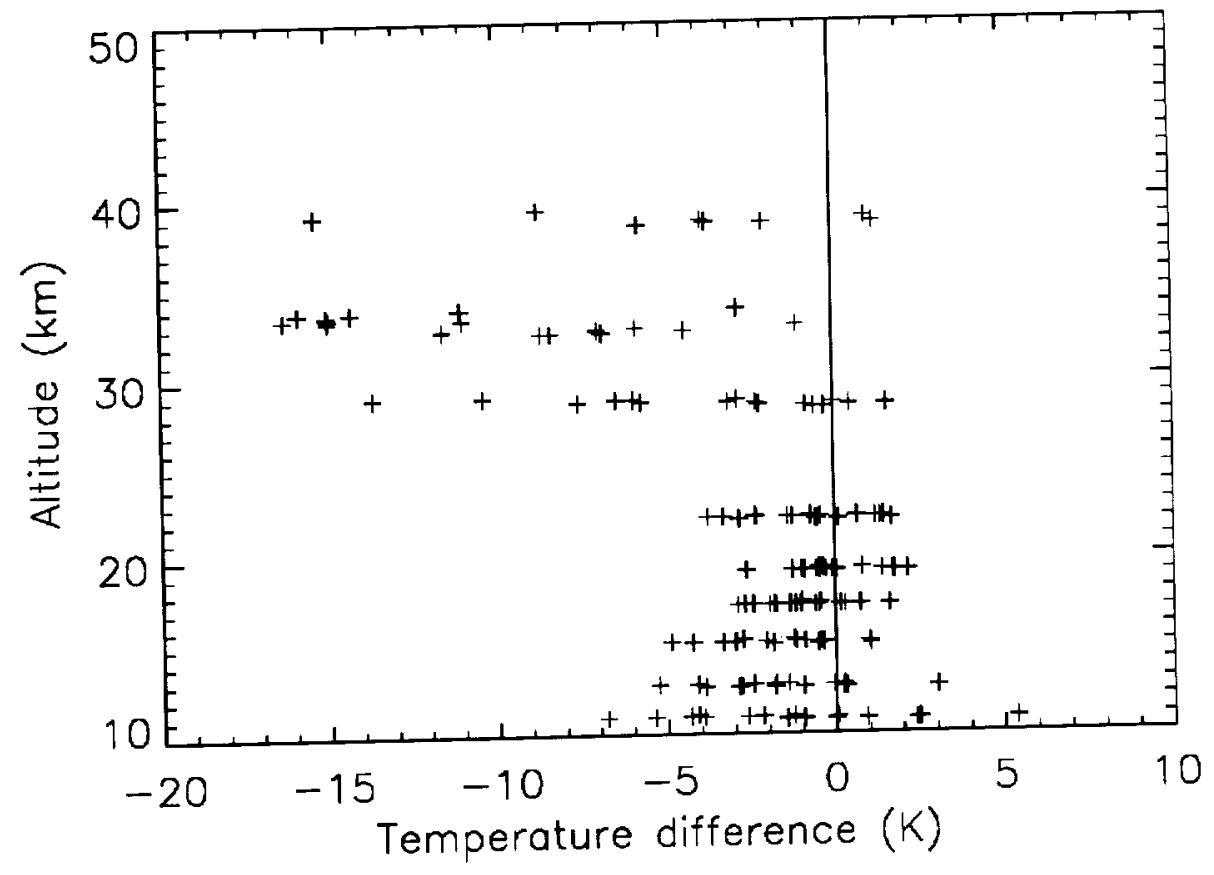

Figure 13 STROZ-LITE minus UKMO model temperatures at Ny Ålesund during the 1998 NDSC campaign. Differences between STROZ-LITE and UKMO were calculated between 10 and $\sim 40 \mathrm{~km}$ altitude. The mean difference was $-2.7 \pm 4.2 \mathrm{~K}$. There was a slight cold bias of $\sim 1 \mathrm{~K}$ from 10 to $22 \mathrm{~km}$ which increased to over $9 \mathrm{~K}$ at 32.6 $\mathrm{km}$. Reported temperature errors for these data sets range from $0.1 \mathrm{~K}$ at $10 \mathrm{~km}$ to $0.3 \mathrm{~K}$ at $38 \mathrm{~km}$ with an effective vertical resolution of between 1 and $3 \mathrm{~km}$. 


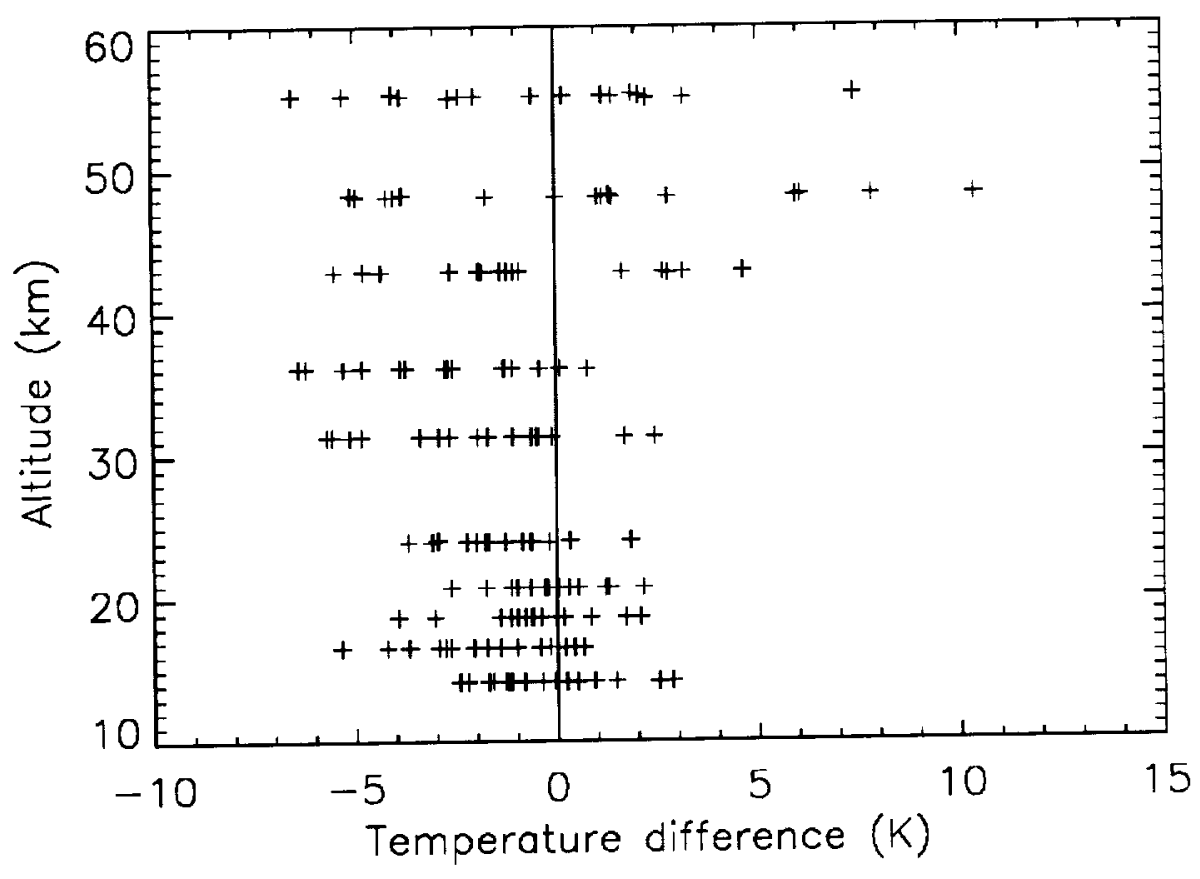

Figure 14 STROZ-LITE minus UKMO model temperatures during the Mauna Loa NDSC correlative measurements campaign in 1995. Data was acquired on 16 dates from August $15^{\text {th }}$ through September $1^{\text {st }}$. A slight cold bias was noted between 30 and $40 \mathrm{~km}$, at $31.3 \mathrm{~km}$ the mean difference between lidar and UKMO was $-2.0 \pm 2.5 \mathrm{~K}$ and at $36.1 \mathrm{~km}$ it was $-2.8 \pm 2.2 \mathrm{~K}$. Differences were calculated from 14.2 to 55.2 $\mathrm{km}$ with a mean difference of $-0.9 \pm 2.7 \mathrm{~K}$. Calculated uncertainties ranged from $\sim 0.1 \mathrm{~K}$ to $\sim 0.6 \mathrm{~K}$ at $55 \mathrm{~km}$. The lidar's resolution ranged from $1 \mathrm{~km}$ at $14 \mathrm{~km}$ to $\sim 3 \mathrm{~km}$ at $30 \mathrm{~km}$ and $\sim 2 \mathrm{~km}$ at $55 \mathrm{~km}$. 


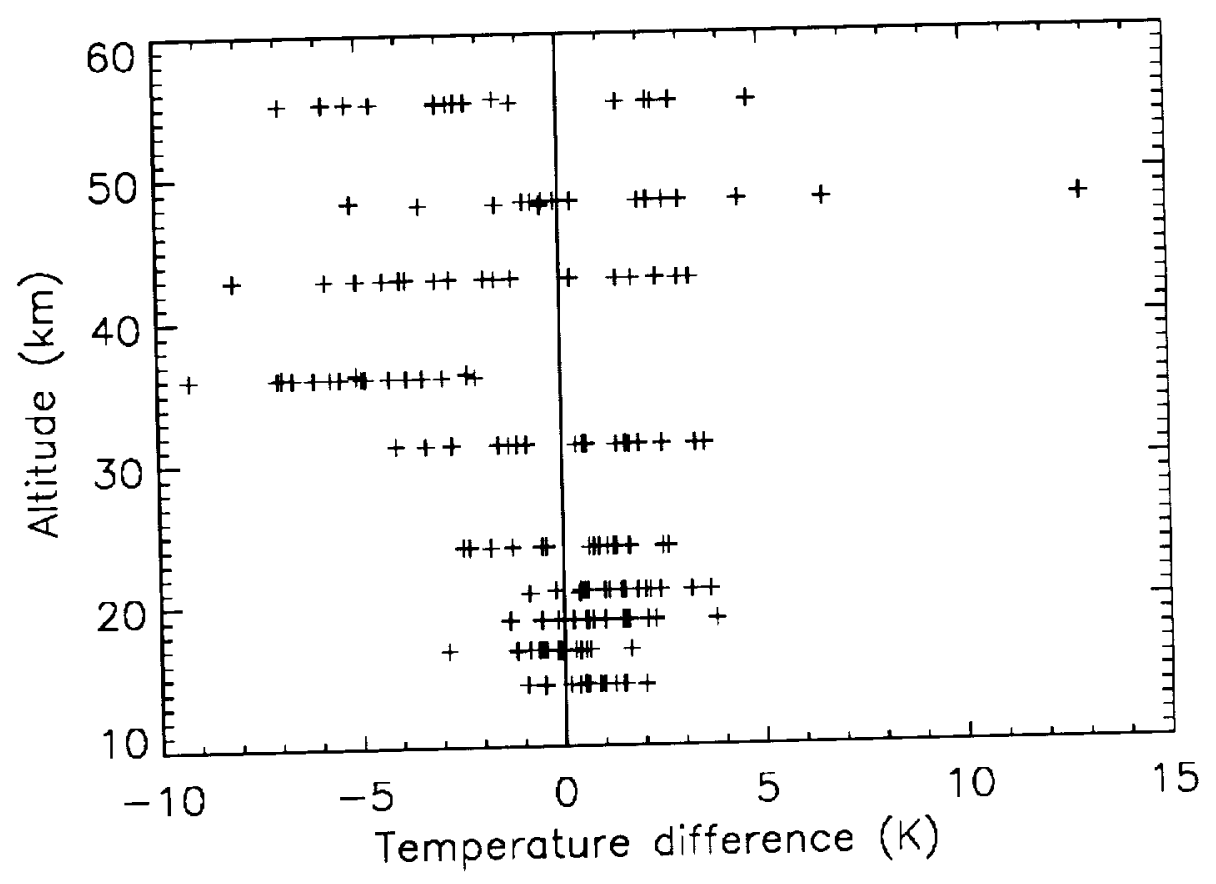

Figure 15 JPL - UKMO model temperatures during the Mauna Loa NDSC campaign in 1995. The JPL data had a slight cold bias of $-0.5 \pm 3.0 \mathrm{~K}$ averaged between 14.3 and $55.4 \mathrm{~km}$ altitude. The largest bias, $-5.0 \pm 1.8 \mathrm{~K}$, was observed at $36.0 \mathrm{~km}$. Typical errors for the JPL measurements ranged from 0.2 to $1.0 \mathrm{~K}$ with a reported vertical resolution of from $\sim 1.0$ to $7 \mathrm{~km}$. 


\section{Summary of paper designed for the general public.}

\section{Validation of Temperature Measurements from the Airborne Raman Ozone Temperature and Aerosol Lidar During SOLVE}

During the winter of 1999/2000, the SAGE III Ozone Loss and Validation Experiment (SOLVE) mission took place in Kiruna, Sweden. This campaign was designed to further our understanding of how ozone is destroyed in the Arctic atmosphere at altitudes of from $45,000^{\prime}$ to $75,000^{\prime}$ during the winter. NASA's Goddard Space Flight Center flew a new instrument, the Airborne Raman Ozone, Temperature and Aerosol Lidar (AROTEL), on NASA's DC-8. This instrument consisted of two lasers, a telescope and electronics designed to measure aerosols/clouds, ozone and temperature to beyond 100,000' altitude. Temperatures below $-117^{\circ} \mathrm{F}$ were repeatedly measured. AROTEL temperatures were compared against those made at the flight altitude of NASA's ER-2, approximately 60,000 ', when both instruments sampled the same parcel of air. AROTEL temperatures were from 3-5 ${ }^{\circ} \mathrm{F}$ colder than those measured on the ER-2. When compared against temperatures measured by a temperature sonde attached to a high flying balloon, temperature differences were approximately $2^{\circ} \mathrm{F}$. These measurements were uncertain to approximately $2^{\circ} \mathrm{F}$. Comparisons between AROTEL temperatures and those made by the HALOE instrument on the UARS satellite, showed agreement to within $9^{\circ} \mathrm{F}$ which is similar to previous temperature measurements made by HALOE when compared to other lidars. 